\title{
Emergency and Medical Management of Accidental Ingestion of Yellow Phosphorus-based Rat Bait in a Dog
}

\section{Saravanan $\mathrm{M}^{1 *}$, Yogespriya $\mathrm{S}^{2}$, Ramkumar $\mathrm{PK}^{1}$, Kannan $\mathrm{K}^{1}$ and Senthilkumar $\mathbf{S}^{1}$}

${ }^{1}$ Veterinary Clinical Complex, VCRI, Thanjavur, TANUVAS Chennai, India

${ }^{2}$ Department of Veterinary Medicine, VCRI, Thanjavur, TANUVAS Chennai, India

*Corresponding Author: Saravanan M, Veterinary Clinical Complex, VCRI, Thanjavur, TANUVAS Chennai, India.
Received: October 13, 2021

Published: October 26, 2021

(C) All rights are reserved by Saravanan M., et al.

\begin{abstract}
Accidental ingestion of toxicant/poison is common issues in the pets, such kind of a case of one and half year-old Mongrel dog with the history of accidental ingestion of rat kill paste (Ratol@TM) about 2 hrs back, presented to the Veterinary Clinical Complex, VCRI, Orathanadu. Clinical examination revealed panting, tachycardia, dilated pupil and vomiting. Dog was provided with support was done and gastric lavage was done, followed by dog was kept in CCU for further monitoring. Hematology revealed mild anemia. Serum biochemical and blood gas analysis were within the reference interval. Dog was stabilized with fluids, antibiotics, antiemetic and provided supportive care. Acetylcysteine was initiated as protective measures to prevent acute hepatic damage. Further fluid therapy and supportive care continued for 6 hrs and dog improved by the 3rd hour onwards. The dog was successfully recovered with its normalcy. This case documented recovery followed emergency care which was instituted within 2 hrs.
\end{abstract}

Keywords: Ratol ${ }^{\circledR T M}$ Paste; Rodenticide; Yellow Phosphorus; Acetylcysteine; Gastric Lavage

\section{Introduction}

Accidental poisoning in pets is most frequently encountered problem due to over-the-counter medications and use of toxicants for the control of pest, flies, cockroaches and rodents in the household, kitchen, yard and garden also chance to acquire toxicity in pets [1-3]. Rodenticides are commonly using compound to control rodent in household and food/fodder storage unit, among the various types of rodenticides Yellow Phosphorus based rodenticides are commercially available as bait and it's highly fatal to human as well as animals when consumed accidentally or deliberately [4]. Yellow Phosphorus is rapidly absorbed from the gastrointestinal tract and metabolized in liver further it causes multi organ failure [5]. Oral lethal dose of Yellow Phosphorus in dogs is 3-6 mg per kg bwt [6]. The commonly reported rodenticide poisoning in dogs is due to Warfarin, but Phosphorous based rodenticide poisoning in pets were not well documented. Hence, the present case was documented accidental ingestion of yellow Phosphorous based Ratol paste in a dog and its successful medical management.

\section{Materials and Methods}

The present case was recorded at Emergency and Critical Care Medicine Unit of Veterinary Clinical Complex, Veterinary College and Research Institute, Orathanadu. A one and half year-old Mongrel dog was presented with the history of accidental ingestion of rat kill paste (Ratol@TM) about 2 hrs back and owner brought the Ratol paste (3\% Phosphorous) which was eaten by dog. Clinical findings revealed dilated pupil, panting, tachycardia and vomiting. 
As Rat bait poisoning was diagnosed, the dog was shifted to Critical Care Unit.

Emergency care: Initially animal was sedated with Inj. Xylazine @ 1.1.mg/kg and Inj. Diazepam @ 0.5mg/kg IV to institute respiratory support with endotracheal intubation. Gastric lavage was done with diluted potassium permanganate and stomach contents were evacuated. Dog was kept under fluid therapy and supportive care and dog was kept in CCU for further monitoring. Blood sample was collected to evaluate hemato-biochemical changes and Arterial blood was collected to assess blood lactate by Point of care handheld Arterial blood gas analyzer (Abbott I-STAT). FAST abdominal ultrasound was performed to check abdominal abnormalities. Dog was stabilized with fluids Inj. Ringers lactate, Inj. Benzyl penicillin @ 10000 IU/kg IV, Inj. Ondansetron @ 0.5 mg/kg IV, Inj. Ranitidine @ $2 \mathrm{mg} / \mathrm{kg}$ IM along with supportive therapy Inj. Acetylcysteine @ $10 \mathrm{mg} / \mathrm{kg}$ IV was initiated as protective measures for acute hepatic damage. Further fluid therapy and supportive care continued for 6 hrs and dog was improved by the $3^{\text {rd }}$ hour onwards.

\section{Results and Discussion}

Most of the pets accidentally get poisoned at home itself, as they sometimes eat things like repellants, paints, rodenticides and household cleaners. In the present case, the dog had accidental ingestion of rat bait paste and it was managed successfully. According to the authors knowledge, there is no report on accidental ingestion of Yellow Phosphorous based (Ratol @TM) poisoning in a dog. RATOL is a popular brand of yellow phosphorous which is freely available in the form of pastes containing 2-5\% of yellow phosphorous in India [7]. There is lack of reference for dogs with Yellow Phosphorous poisoning, author cited literatures of human cases of Yellow Phosphorous poisoning, because and the pharmaco-toxicological effects between human and dogs are same.

Yellow phosphorous poisoning is common in children as the paste is mistaken for toothpaste, or bread smeared with this paste as bait could be accidentally consumed [8,9]. Ingestion of fireworks is another common mode of poisoning in Southeast Asia, commonly seen in children and young adults [10].

Yellow Phosphorous is a corrosive agent which rapidly absorbed in gastrointestinal tract and production of phosphoric acid leads severe erosion and further accumulated in tissues mainly in liver and directly causes tissue damage due to the production of free radicals [11,12]. Mohideen and Kumar [9] reported that there is no specific antidote for Phosphorous poisoning and only symptomatic treatment protocols like early decontamination of poisoning by gastric lavage with 1:5000 potassium permanganate followed by activate charcoal administration and supportive care [13] and the present case also managed with similar ways.

$\mathrm{N}$-acetylcysteine is an antioxidant, hepatoprotective and reduces tissue damage caused by toxicants which improves by mitochondrial energy metabolism and acts as a scavenger of oxygen free radicals [14]. Nalabothu., et al. [15] and Shukkoor., et al. [16] reported $\mathrm{N}$-acetylcysteine administration gives very good prognosis in yellow Phosphorous induced hepatic injury. Hence, the present case also acetylcysteine was administered to prevent hepatic damage due to ratol paste poisoning.

\begin{tabular}{|c|c|c|c|}
\hline $\begin{array}{l}\text { Param- } \\
\text { eters }\end{array}$ & $\begin{array}{l}\text { Measured } \\
\text { value }\end{array}$ & $\begin{array}{c}\text { Reference } \\
\text { range }\end{array}$ & \\
\hline $\mathrm{Hb}(\mathrm{g} / \mathrm{dL})$ & 7.4 & 11.9-18.9 & \multirow{7}{*}{$\begin{array}{c}\text { Fielder [17] } \\
\text { (MSD Veterinary } \\
\text { Manual) }\end{array}$} \\
\hline PCV (\%) & 32 & $35-57$ & \\
\hline $\begin{array}{l}\text { RBC (x } \\
\left.10^{6} \mathrm{ul}\right)\end{array}$ & 3.05 & $4.95-7.87$ & \\
\hline $\begin{array}{l}\text { WBC (x } \\
\left.10^{3} \mathrm{ul}\right)\end{array}$ & 8.15 & $5-14.1$ & \\
\hline $\begin{array}{l}\text { BUN (mg/ } \\
\text { dL) }\end{array}$ & 16 & $8-28$ & \\
\hline $\begin{array}{l}\text { Creatinine } \\
(\mathrm{mg} / \mathrm{dL})\end{array}$ & 0.76 & $0.5-1.7$ & \\
\hline $\begin{array}{l}\text { ALT (mg/ } \\
\text { dL) }\end{array}$ & 15 & $10-109$ & \\
\hline $\mathrm{pH}$ & 7.47 & $7.32-7.45$ & \multirow{5}{*}{$\begin{array}{c}\text { Waddell [18] and } \\
\text { Humm [19] }\end{array}$} \\
\hline $\begin{array}{l}\mathrm{PCO}_{2} \\
(\mathrm{mmHg})\end{array}$ & 22.5 & $40-50$ & \\
\hline $\begin{array}{l}\mathrm{PO}_{2} \\
(\mathrm{mmHg})\end{array}$ & 62 & $30-42$ & \\
\hline $\begin{array}{l}\text { Beecf } \\
(\mathrm{mmol} / \mathrm{L})\end{array}$ & -7 & $-4-+4$ & \\
\hline $\begin{array}{l}\mathrm{HCO}_{3} \\
(\mathrm{mmol} / \mathrm{L})\end{array}$ & 19.5 & $20-24$ & \\
\hline $\begin{array}{l}\text { Lac } \\
(\mathrm{mmol} / \mathrm{L})\end{array}$ & 1.42 & Less than 2.9 & $\begin{array}{c}\text { Thorneloe., et al. } \\
{[20]}\end{array}$ \\
\hline
\end{tabular}

Table 1: Changes in hematobiochemical and blood gas levels due to yellow phosphorus-based rat bait in a mongrel dog. 
In the present case biochemical and blood gas assay revealed normalcy. Brent., et al. [11] reported that increased liver enzymes will be appreciated after 2-3 hrs of poisoning due to Phosphorous intoxication. Hence, in the present case was brought to hospital with in 2 hrs of ingestion, this may be the normalcy in the both biochemical and blood gas level.

In this case dog showed anemic $(7.4 \mathrm{~g} / \mathrm{dl})$ picture, it may be due to pet was already had anemic episode, because with in the short period of exposure with rat paste poison may not alter the hematology values. Focused Assessment Sonography (FAST) ultrasound revealed normalcy of abdominal organs.

\section{Conclusion}

Yellow Phosphorous based rat bait is usually fatal in nature and successful recovery is challenging one. If cases are presented more than 8 hrs of ingestion then survival may be questionable. This case documented recovery following emergency care which was instituted within 2 hrs. Prevention is better than cure, hence the pet parents should take care their pets to avoid accidental poisoning by their negligence.

\section{Acknowledgements}

The Authors are grateful to The Director of Clinics TANUVAS and The Dean VCRI Orathanadu for all the facilities provided for carrying out this study.

\section{Conflict of Interest}

Authors Declare NO conflict of interest.

\section{Bibliography}

1. Lee JA. "Emergency Management and Treatment of the Poisoned Small Animal Patient". Veterinary Clinics: Small Animal Practice 43 (2013): 757-771.

2. Kannan K., et al. "Meloxicam Toxicity in Labrador Dog Due to Dispensing Error and its Reversal by Misoprostol". Indian Veterinary Journal 96.10 (2019): 78-80.

3. Saravanan M., et al. "Reversal of Hepato-renal Impairment Induced by Meloxicam Paracetamol Toxicity in a Labrador Dog". Toxicology International 28.1 (2021): 81-89.

4. Hiran S. "Ventricular Arrhythmia Due to Yellow Phosphorus Poisoning". Journal of Case Reports and Studies 5.3 (2017): 303.
5. Ghoshal AK., et al. "The role of lipo-peroxidation in the pathogenesis of fatty livers induced by phosphorus poisoning in rats". American Journal of Pathology 54 (1969): 275-91.

6. Clarke EGC and Clarke ML. "Veterinary Toxicology". Bailliere Tindall, London (1975).

7. D'Silva C and Krishna B. "Rodenticide Poisoning". Indian Journal of Critical Care Medicine 23 (2019): S272-S277.

8. Mauskar., A. "Acute hepatic failure due to yellow phosphorus ingestion". Indian Journal of Pharmacology 43.3 (2011):355356.

9. Mohideen SK and Kumar KS. "Should ratol paste be banned?" Indian Journal of Critical Care Medicine 19.2 (2015): 128-129.

10. Yuksekkaya H., et al. "Ingestion of fireworks: rare cause of poisoning in children". Pediatric Emergency Care 35.3 (2019): 216-219.

11. Brent J., et al. "Critical Care Toxicology - Diagnosis and Management of the Critically Poisoned Patient". Philadelphia, PA: Elsevier Mosby (2005): 851-861.

12. Kharkongor MA. "Early use of intravenous N-acetylcysteine in treatment of acute yellow phosphorous poisoning". Current Medical Issues 15 (2017):136-138.

13. Saoji AA., et al. "A Case on Suicidal Poisoning Associated with Ratol and a Perspective on Yellow Phosphorus Poisoning". International Journal of Food Science and Technology 10 (2014): 223-225.

14. Zwingmann $\mathrm{C}$ and Bilodeau M. "Metabolic insights into the hepatoprotective role of $\mathrm{N}$-acetylcysteine in mouse liver". Hepatology 43 (2006): 454-463.

15. Nalabothu M., et al. "Clinical profile and outcomes of rodenticide poisoning in tertiary care hospital". International Journal of Science and Research 5 (2015):1-12.

16. Shukkoor AA., et al. "N-Acetylcysteine, A Boon For Yellow Phosphorus-Induced Acute Liver Failure? A Case Report". Asian Journal of Pharmaceutical and Clinical Research 12.8 (2019): 1-3.

Citation: Saravanan M., et al. "Emergency and Medical Management of Accidental Ingestion of Yellow Phosphorus-based Rat Bait in a Dog". Acta Scientific Veterinary Sciences 3.11 (2021): 57-60. 
17. Fielder SE. "MSD Veterinary Manual” (2015).

18. Waddell LS., et al. "Blood Gas Analysis. Management Tree". NAVC Clinician's Brief, January (2012): 18-19.

19. Humm K. "How to Interpret Arterial Blood Gas". In WSAVA/ FECAVA/BSAVA World Congress (2012): 11-15.

20. Thorneloe C., et al. "Evaluation of a hand-held lactate analyzer in dogs". Canadian Veterinary Journal 48.3 (2007): 283-288.

Volume 3 Issue 11 November 2021

(C) All rights are reserved by Saravanan M., et al. 